\title{
Proceeding
}

Supplementary Issue: Winter Conferences of Sports Science. Costa Blanca Sports Science Events, 25-26 January 2019.

Alicante, Spain

\section{Innovative educational methodologies and corporeity factor}

\author{
ANTONIO ASCIONE, DAVIDE DI PALMA $\triangle$, ROBERTA ROSA \\ Department of Motor and Well-being Sciences, University Parthenope of Naples, Italy
}

\begin{abstract}
The aim of this paper is to support the experimentation of new integrated educational methods to promote the development of new knowledge. Through the involvement of the body it is possible to make training "real"; that is: making it become effective through learning practices to transformation that is significant from an educational and lifelong learning point of view. In the training field, the tool that can represent the reciprocity between theory and practice is the laboratory; in the existential realm, the effectiveness of the interdependence between thought-action is embodied by corporeity. Therefore, the two key words "laboratory" and "corporeity" allow accessing the realm of the theory and that of pedagogical practice, placing it on the ground of contact and relationship in which experimentation, transformation and innovation are generated. Therefore, everything is explicit in the need to hypothesize models of school and social education that bestow back greater legitimacy to the laboratory and to the effectiveness of corporeity, and in which it is possible to realize not only real opportunities to experiment the potential of each type of knowledge, but above all the implicit transformative potential in the possibility of combining them together. Key words: Laboratory; Corporeity; Experimental pedagogy; Integrated educational methods; School and social formation.
\end{abstract}

\section{Cite this article as:}

Ascione, A., Di Palma, D., \& Rosa, R. (2019). Innovative educational methodologies and corporeity factor. Journal of Human Sport and Exercise, 14(2proc), S159-S168.

doi:https://doi.org/10.14198//hse.2019.14.Proc2.02

Corresponding author. Department of Motor and Well-being Sciences, University Parthenope of Naples, Naples, Italy.

E-mail: davide.dipalma@uniparthenope.it

Supplementary Issue: Winter Conferences of Sports Science. Costa Blanca Sports Science Events, 25-26 January 2019. Alicante, Spain.

JOURNAL OF HUMAN SPORT \& EXERCISE ISSN 1988-5202

(C) Faculty of Education. University of Alicante.

doi:10.14198/jhse.2019.14.Proc2.02 


\section{INTRODUCTION}

Movement is the main way to express oneself, communicate and understand. Since their birth, human beings learn to know each other, their own body and the emotions that live inside it, in order to be aware of themselves and their identity through the body experience, exploring and discovering their potentialities and expressive-communication-relational skills, thus rediscovering themselves and their emotional, personal and social potentiality. All the experiences involving corporeity and emotional sphere strongly influence the identity of every human being. The educational and social value of the movement is recognized and promoted internationally, and is combined with a reconsideration of the concepts of health and well-being, taking on increasing importance in the lives of all human beings with or without disabilities (De Vita e Rosa, 2018). The promotion of corporeity to stimulate the subject's training development, both at individual level and in relation to others, is therefore an opportunity that must not be neglected. The strategy with which this can become concrete is the laboratory activity that tends to turn what is usually only theoretically expressed into practice. This contribution wants to be an incentive for the development of the possibility of favouring more and more the presence of laboratories on the corporeity also in the school system, and mainly as regards the discipline of Motor and Sports Education that, in addition to traditional-type didactics focused on physical exercise and sports practice, can thus set itself as a pedagogical science and develop its full potential towards students and their growth path. In this regard, an experimental proposal that includes the integration of a laboratory on corporeity, focusing on Biodanza SRT methodology within a class of a second level educational institution, and with the aim of assessing the student's perception of his own potential educational, didactic and pedagogical development, is here analysed.

\section{The Corporeity Factor as an Educational tool}

The Body in Motion turns out to be a real motor, educational, cognitive, functional and relational laboratory in which each person "experiences himself, relationships and life". Body and corporeity are fundamental mediums for the development of identity, of the skills for understanding what happens and surrounds us, of knowledge and abilities, of communication and intimate relationship with oneself and with all that is outside of us, being "a bridge" towards each other and the world. And what is external to us (people, objects, environments) is extremely crucial for the development of our identity and our life quality. Identity is the uniqueness that represents every single person in his biological, psychological, affective, social and cultural characteristics. It is rooted in the genetic structure of each person, with a biological expression that follows a development process that also depends on environmental factors, such as: interaction with other people, the action of positive eco-factors that can promote harmonious growth (love, nurturing, care) or negative ecofactors that can generate stress (hunger, lack of affection, lack of care), and even with dominant social models often providing a boost to adapt to behavioural stereotypes that in our culture, for example, turn out to be "conformist" by making people lose their own identity and become robots. Recovering the sense of identity, the ability to empathize, to be protagonists of one's own life with respect for the value and dignity of others thus become primary objectives and key elements on which to focus an educational intervention. Motor experiences allow developing the ability to acquire one's own physical self-sense, interpreting and ruling over one's own body, by also playing a transversal fundamental role that can be combined with other fields of experience (the self and the other, images, sounds, colours, speeches and words, and the knowledge of the world). There is no cognitive experience without the implication of the corporeal-emotional experience a subject has been through. The experimentation of the environment is conveyed and mediated by the body, a fundamental step both to come to know the sense of identity and to foster a perspective for observing oneself, the others and the environment. Therefore, body mediation and non-verbal, analogical, expressivemotor, playful and imitative communication skills are essential for the construction and creation of welcoming and inclusive educational environments too. Body-mediated motor activities grant the space in which to 
confront oneself with others, grow together and acquire tools that allow developing the relationship with oneself and with others. In this perspective, motor activity must be considered as a multi-purpose tool, capable of acting also and mainly on all human components: that physical, neuro-psychic, physiological, social and human; in short terms, on the person and his identity: a strategy to be privileged in order to stimulate its renewal process, a positive self-assessment, and self-esteem. Thinking about learning, we immediately think back to the image of children and to the evolutionary development of education. But education and learning last a lifetime. We educate ourselves by learning from others, from nature, from life with or without disability or "diversability". "Corporeity does not only concern the initial time of the child's first explorations, but it concerns a whole lifetime, and thus learning processes are linked to an infinite time too, which is the dimension of 'Lifelong learning' "(De Anna, 2012). Through a neuro-didactic approach of the research, Body and Movement have been recognized as accelerators of human learning processes (Sibilio, 2005), being them elective learning paths in which the information (with an emotional nuance) does not only find more easily the paths to the long-term memory, but it is also ready to be recalled (Friedrich, Preiss, 2003). Thanks to researches and studies on the subjects of corporeity and movement, two major areas of interest are also affirmed: the multiple intelligences and the enhancement of the role of emotions in learning (Borgogni, 2016).

Starting from Gardner, with his theories on the plurality of intelligences, the scientific community in the last twenty years has offered an original interpretation of the different forms of human cognition, recognizing the corporeal dimension not only the same dignity of the other intellectual forms that characterize men, but the dimension through which these can take place, become concrete and turn into a possibility of expression. Thus the relationship between a subject and learning changes, and so does the contextual review of the relationship between corporeality and cognitive mechanisms, building a new educational-training perspective (Gardner, 1999). In addition, further studies emphasize how emotions can both influence and modify learning processes, and change a neural map, thus becoming a fundamental factor to facilitate or not the memory, whether it is positive or negative (Berthoz, 2003, Damasio, 1994, Edelman, 1993; Le Doux 1996, Goleman 1995).

\section{The role of the Embodied Cognitive Science}

From the field of the "Embodied Cognitive Science", in order to confirm the rooting of cognitive functions in the body, observations and theories showing the close relationship between motor activities, emotions, learning and memory systems have been worked out (Pouw, van Gog 2014). Starting from the assumption of the centrality of the emotional-corporeal dimension as the foundation of the cognitive processes involved in the development, and from Neuroscientific studies concerning the enhancement of the extended corporeity (mind-body-emotions), the paradigm of the Embodied Cognitive Science has been developed; it recognizes in corporeity the primary dimension for the success of the processes influencing and guiding the changes in human behaviour, through which we also perform related actions and relationships. According to the theory of the embodied cognition every form of human cognition is embodied, i.e. it is rooted in the corporeal experience. Also apparently more "abstract" cognitive activities are, in fact, transformations of more basic corporeal experiences. A basic element for cognition is the sense-motor coupling between organism and environment, based on embodied and enactive approaches. According to the concept of "enaction", theorized and worked out by Maturana and Varela (1980), in its phenomenal plurality, cognition corresponds to a form of embodied action dependent on different types of sensory, motor, biological, psychological and cultural experiences (Carboni, 2013). According to the enactive perspective, the human being perceives reality through a continuous interrelationship between the corporeal and the environment through perceptive acts, aimed at the discernment of how, for example, the objects are presented, by examining them with the eye or by feeling their surface with the hands. Depending on our needs and our emotional condition, the surrounding 
objects may seem attractive, interesting, significant or threatening and repulsive. The human being does not perceive the world from a neutral and detached position, because affectivity is the primary way through which an organism attaches meaning to an object, an environment or a lived experience (Galbusera, Fuchs, 2013). Subjective experience and corporeity are therefore correlated and are both central aspects for cognition (Thompson, 2007). Our mental processes develop and are modulated by corporeity. It is the body that, starting from the prenatal age, allows us encountering the world. All that is lived, experienced, embodied, has no skills or disabilities. The experience can be facilitating in all cases without any "constraint of normality".

\section{Corporeity as a pedagogical strategy for the development of forms of intelligence}

The body is the bridge that projects us towards the other and the world, and diversity becomes a resource when it comes into a relationship. We work differently even if we are in the same context, for we are original, one-of-a-kind, unique! Gardner (1975), with his work The Shattered Mind, developed the first hypotheses on the theory of the Multiple Intelligences, asserting the existence of seven different types of intelligences:

- Linguistic intelligence: it represents the ability to know how to listen and master the word. It is the ability to communicate and express oneself through language.

- Logical-mathematical intelligence: it is typical of those who are skilled in calculating, quantifying and solving problems.

- Musical intelligence: it is the ability to communicate through sounds and to process them.

- Spatial intelligence: it is the ability to perceive shapes and colours, spatial relationships, and to obtain and process information relating the external world.

- Corporeal-kinaesthetic intelligence: it is the ability to control one's own body and the coordination of movements.

- Interpersonal Intelligence: it is the ability to understand each other's emotions and desires. Individuals with this ability set up relationships based on empathy.

- Intrapersonal intelligence: it is the ability to be aware of one's own emotions and to be able to manage them.

Subsequently, he added two other types of intelligence: naturalistic intelligence, which refers to the ability to identify and understand the natural environment, and existential intelligence, which refers to the ability to reflect on universal conceptual categories. Gardner offered the scientific community an original and innovative interpretation of the different forms of human cognition, by opening a scientific window on the different channels and cognitive styles that lie in each person. With Intrapersonal Intelligence, Gardner referred to the recognition and management of feelings; it is a type of intelligence which is very similar to the one what will later be defined as emotional intelligence. It is also described as the ability to access the realm of one's own affects and emotions, to instantly distinguish these symbolic feelings, to draw upon them as a means to understand and guide one's own behaviour, and to distinguish a sense of pleasure from a sense of pain. Over time, more and more important has become the construct of "emotional intelligence", that is, the ability to understand and use at best one's own inner experiences and those of others, which translates into greater self-confidence, adaptability and empathy: all factors contributing to social success.

Salovey and Mayer (1990) contributed significantly to the research activity in this field, and gave a definition of emotional intelligence as "the ability to monitor one's own and others' emotions, to discriminate among them, and to use the information to guide one's thinking and actions". Emotional intelligence, therefore, is seen as an ability to identify emotions, use them in a functional way, understand and manage them. In 1995, Goleman published the book "Emotional Intelligence" and defined it as the "ability, developed during 
childhood, to recognize our feelings and those of others, to motivate ourselves, and to manage our emotions positively, both inwardly and in social relationships" (Goleman, 1995). The five categories of the Emotional Intelligence are:

- Self-Awareness (ability to understand one's own emotions).

- Self-regulation (ability to control one's own emotions).

- Motivation (ability to dominate emotions to reach a goal).

- Empathy (ability to recognize the emotions of the others, his desires and needs).

- Social skills (ability to have good interpersonal relationships).

These skills are the key to success in both private and social life. All the different forms of Intelligence, however, have a common source: affectivity. Pedagogy already affirmed that the affective nuance of an event facilitates the memory, and that the emotional intelligence is the ability to feel the other, to empathize and understand him, to dedicate oneself to him (Toro Araneda, 2012).

\section{Laboratory \& Corporeity}

In the education to Corporeity, all the disciplines that place the body at the centre of their experience become fundamental. Therefore, motor and sports activities become excellent didactic strategies. Moreover, when these activities orient their objectives towards development and equality, breaking down the barriers to inclusion, the concept of education to corporeity for health and proper development is fully respected too (Peluso Cassese, 2018).

These are all those innovative didactic models aimed at developing learning processes through corporeality, a context of circular relationships, use of creativity, attention to the body, development of an ecological mind aimed at integrating a balance between pleasure and responsibility (Gamelli, 2011). With this in mind, we take part in the great societal challenges such as the improvement of health and well-being, the overall vision of the person in his physical-mental and relational dimensions, the improvement of individual performance skills, the management of conflict situations and differences, the educational development, the integration of disabled people or people from different cultural backgrounds. Through laboratory-based experiences focused on the movement, we come into contact with our emotional world, and into relationship with others. The archaic and shared language of emotions allows us feeling part of the social context in an authentic way (Le Boulch 1991, Fabbroni 2004, Dewey 2010).

"Knowing how to do" instead of "knowing that" allows becoming aware of why we need to know something and how some knowledge can be exploited. In this way, the integration between previously-acquired knowledge and new knowledge is activated (Mortari 2003). The strategy to learn (meaning it not only memorizing, but also and above all understanding) are improved. Socialization, social integration, cooperation and the valorisation of others are encouraged; aggressiveness and competitiveness are decreased in favour of a social responsibility aware of the collective well-being.

An important lesson is also that to support the courage to experiment with new integrated educational modalities, going beyond the certainties provided by the traditional models to promote the development of new knowledge. Through the involvement of corporeity it is possible to make the education "real", i.e. to effectively realize, through learning practices, a transformation that is meaningful from the educational point of view and that of lifelong learning. In the field of education, the tool able to represent the reciprocity between theory and practice is the laboratory; in the existential field, the effectiveness of the interdependence between thought and action is embodied by corporeity. Therefore, the two key words laboratory and corporeity allow 
accessing the realm of the theory and that of pedagogical praxis, placing itself on that ground of contact and relationship in which transformation and innovation are generated. In this way, everything is explicit in the need to hypothesize training models that bestow back greater legitimacy to the laboratory and to corporeal effectiveness, and in which it is possible to realize real opportunities to experiment not only the potential of each type of knowledge, but above all the transformative potential inherent in the possibility to combine them together. The result is an effective training to reflexivity and self-knowledge to be understood as a preparatory moment of training for those self-efficacy and empowerment processes. The innovative educational methodologies drive the search for methods of "training" to "know how" (here understood also in the sense of tasting it, i.e. experiencing it and enjoying committing oneself to make something real), to experiment through the exercise of all of one's own resources: those bodily, affective-emotional and mental.

\section{Experimental Approach in the School System: Laboratory on Corporeity in Motor and Sports Education}

The experimental proposal includes the evaluation of a laboratory on corporeity in a school context, in terms of effectiveness in the pedagogical and didactic development of the students towards motor and sports sciences. The evaluation is oriented towards students' perspective, and their perception of usefulness of the laboratory activity as an important and innovative element in support of the classical educational methodologies of the school context for motor and sports activity. The Innovative Methodology used for the Laboratory on corporeity is the Biodanza SRT. It proposes experiences lived in the "group" and is based on an experimental pedagogical system founded on the simultaneous development of the individual and the group, in an environment where the parties are dynamically connected, so that the educational growth of the individual generates a benefit to all the others. More specifically, the activity is based on a conception of corporeity that takes advantage of the synergistic action of other components, such as:

- Music (universal language that facilitates self-expression and deeply stimulates emotions and existential sensitivity).

- Movement (a natural expression, something spontaneous, perceived and felt, as a rediscovery of one's own most authentic gestures, full of sense and meaning).

- Vivencia, "Experience lived with great intensity by an individual in the present moment, which involves coenaesthesia, visceral and emotional functions" (Toro Araneda, 2007).

In recent years, the Biodanza SRT system as a methodological-didactic-innovative strategy with body mediation, functional to the physiological learning process, has been introduced in various educational and/or training contexts, attracting considerable interest also in experimentation and research activities aimed at investigating the effectiveness of the didactic-pedagogical tool and its ability to offer its educational value oriented towards:

- The development of affectivity as a founding core for the induction of "Vivencia".

- The related stimulation of positive emotions and of the "Multiple intelligences" starts from the centrality of corporeity as a medium between the self and the world.

- The strengthening of identity, the enhancement of talents and diversity as a resource, the dialogue and the exchange, by restoring quality to human relationships.

Biodanza SRT makes use of motor proposals designed and created to stimulate the ability to perceive others empathically, to foster the expression of positive emotions, to educate to the affectivity of gradually stimulating the whole set of human intelligences, thus contributing to an integrated and healthy development of the person. A key characteristic of the Biodanza SRT system is represented by its universality as it is an 
educational method with a heterogeneous and transversal application, suitable for men and women of all ages belonging to different categories (children, adolescents, adults, seniors, families, professionals, athletes) in multiple contexts (Tafuri et al., 2019).

\section{METHOD}

It is essential to state that the experimentation was based on the collaboration and skills of the motor and sports education teacher of the "sample" class, which was the object of the project.

Teaching Discipline in which the Laboratory on Corporeity was included: Motor and Sports Education. Experimental Methodology object of the Laboratory: Biodanza SRT.

Table 1. Evaluation Test

\begin{tabular}{|c|c|c|}
\hline \multicolumn{3}{|c|}{ MARK WITH AN "X" THE SELECTED RESPONSE (MARK ONLY ONE ANSWER) } \\
\hline & QUESTION & ANSWER \\
\hline 1 & $\begin{array}{l}\text { With respect to the learning of Biodanza SRT, the activities } \\
\text { of the Laboratory on Corporeity you have carried out were: }\end{array}$ & $\begin{array}{l}\text { A. very useful } \\
\text { B. useful } \\
\text { C. not very useful } \\
\text { D. useless }\end{array}$ \\
\hline 2 & $\begin{array}{l}\text { With respect to the learning of Motor and Sports Education, } \\
\text { the activities of the Laboratory on Corporeity you have } \\
\text { carried out were: }\end{array}$ & $\begin{array}{l}\text { A. very useful } \\
\text { B. useful } \\
\text { C. not very useful } \\
\text { useless }\end{array}$ \\
\hline 3 & $\begin{array}{l}\text { The fact of treating arguments through an experimental } \\
\text { activity of the Laboratory on Corporeity made the subject of } \\
\text { Motor and Sports Education: }\end{array}$ & $\begin{array}{l}\text { A. more interesting but not } \\
\text { more difficult } \\
\text { B. more difficult but also more } \\
\text { interesting } \\
\text { C. more difficult and less } \\
\text { interesting } \\
\text { D. less understandable }\end{array}$ \\
\hline 4 & $\begin{array}{l}\text { In the overall, did you like the activities of the Laboratory on } \\
\text { Corporeity you have carried out? }\end{array}$ & $\begin{array}{l}\text { A. a lot } \\
\text { B. enough } \\
\text { C. a little } \\
\text { D. not at all }\end{array}$ \\
\hline 5 & $\begin{array}{l}\text { The results of the Motor and Motor Education tests carried } \\
\text { out at the end of the activities of the Laboratory on } \\
\text { Corporeity, were: }\end{array}$ & $\begin{array}{l}\text { A. better than my expectations } \\
\text { B. in line with my expectations } \\
\text { C. worse than my expectations } \\
\text { D. I didn't carry out any tests }\end{array}$ \\
\hline 6 & $\begin{array}{l}\text { The results of the Motor and Sports Education tests carried } \\
\text { out at the end of the activities of the Laboratory on } \\
\text { Corporeity, were: }\end{array}$ & $\begin{array}{l}\text { A. better than the grade that I } \\
\text { usually record in this subject } \\
\text { B. in line with the vote that I } \\
\text { usually record in this subject } \\
\text { C. worse than the vote that I } \\
\text { usually record in this subject } \\
\text { D. I didn't carry out any tests }\end{array}$ \\
\hline
\end{tabular}

Source: Our Elaboration. 
The sample consists of 19 third school year students of a second grade education institution: 11 males (M) 8 females $(F)$ - average age: 15.7 years.

Duration: 2 Months - 2 Weekly Lessons of 1 hour each - For a total of 16 Lessons (16 hours).

Maximum number of hours of absence for the student to be considered valid element in the experimentation: 2 hours.

Assessment Test Structure: Multiple-choice short questionnaire administered in an "anonymous" form. The test required that response $A$ always corresponded to a high level of evaluation, and that this decreased to the minimum level with answer $D$. The reduced number of questions had the function of minimizing the hypothesis of a "non-response" by the students.

At the end of the 2 months of laboratory activity the students carried out the typical Motor and Sports Education lessons for a month, and then underwent the evaluation test of the experimental projects structured as follows. We outline that the decision to wait one month before the evaluation test was considered opportune in order to allow students having a more accurate and concrete feedback on what they were queried.

\section{Results and Observations}

First of all, it should be noted that 1 student exceeded the 2-hour absence limit and was not subjected to the final evaluation test. The sample was thus reduced to 18 students. Below is the table with the outcomes of the Evaluation Test, which indicate the number of students who have chosen every single possible answer.

\begin{tabular}{cc}
\hline QUESTION & NUMBER OF STUDENTS PER ANSWER \\
\hline $\mathbf{1}$ & $\mathrm{A}: 12-\mathrm{B}: 4-\mathrm{C}: 1-\mathrm{D}: 1$ \\
$\mathbf{2}$ & $\mathrm{A}: 9-\mathrm{B}: 7-\mathrm{C}: 1-\mathrm{D}: 1$ \\
$\mathbf{3}$ & $\mathrm{A}: 13-\mathrm{B}: 3-\mathrm{C}: 2-\mathrm{D}: 0$ \\
$\mathbf{4}$ & $\mathrm{A}: 14-\mathrm{B}: 2-\mathrm{C}: 1-\mathrm{D}: 1$ \\
$\mathbf{5}$ & $\mathrm{A}: 10-\mathrm{B}: 6-\mathrm{C}: 2-\mathrm{D}: 0$ \\
$\mathbf{6}$ & $\mathrm{A}: 10-\mathrm{B}: 6-\mathrm{C}: 2-\mathrm{D}: 0$ \\
\hline
\end{tabular}

Source: Our Elaboration.

The outcomes show a prevalence of Answers $A$ and $B$ with respect to the rest. More specifically: Answers $A$ (68/108) - Answers B (68/108) - Answers C (28/108) - Answers D (68/108). The percentage of Responses A reached about a $63 \%$, and it gets to an $89 \%$ if we add also Answers $B$ to it. This result provides a very important indication of the students' appreciation of a laboratory activity based on corporeity, specifically through the Biodanza SRT methodology, included in a Motor and Sports Education program. Furthermore, their perception of a benefit in the educational growth path at school, in terms of learning of the discipline, is also positive.

The outcome cannot absolutely be conceived as "absolute" for some basic elements, like the reduced number of the sample, its homogeneity in the school environment and the limited duration of the experimentation phase, but also because the student's perspective was analysed; the latter provides a perception of appreciation, but it does not ensure a certainty of the real effectiveness in terms of progress of the school offer in the long run. That said, the educational and pedagogical potential of the inclusion of a training 
approach in the school system, based on the coexistence of laboratory activities on the corporeity in the field of motor and sports sciences, is equally clear.

\section{CONCLUSIONS}

Laboratory and Corporeity are a combination that could characterize the training process which students face within the school system, offering an opportunity for growth through schemes and methodological approaches that are different from the traditional ones, such as the object of the research carried out: the Biodanza SRT. The experimental part of this work assessed, from the student's perspective, that there is a concrete educational, training and didactic potential to be exploited within the school discipline related motor and sports sciences. The work is the basis for future research ideas that could consider an increased sample size and its differentiation both in terms of education and type/address of the school context; moreover, above all, there could be an attempt to measure the didactic, pedagogical and formative effectiveness of a laboratory on corporeity both at school level in other disciplines than the motor and sports ones, and in other individual's non-school relational contexts.

\section{CONTRIBUTIONS}

The manuscript is the result of a collective work by the authors, the specific contribution of which is to be referred to as follows: The Introduction and Paragraphs n. 2 and 4 are to be attributed to Roberta Rosa, Paragraphs n. 1 and 3 to Antonio Ascione, Paragraph n. 5 and the Conclusions to Davide Di Palma.

\section{REFERENCES}

Berthoz, A. (2003). La Décision. Paris: Odile Jacob. Trad. it. (2004). La scienza della decisione. Torino: Codice.

Borgogni, A. (2016) La didattica sostenibile delle attività motorie. Formazione \& Insegnamento XI - 1, supplemento.

Carboni, M. (2012) Le tracce del corpo i riflessi dello sguardo, Pensa Multimedia, Lecce.

Damasio, A. (1994). Descartes' Error: Emotion, Reason, and the Human Brain. New York: Putnam (trad. it. L'errore di Cartesio Adelphi, Milano.

De Vita, T., Rosa, R. (2018). Motor Activity, Corporeity, Education, Inclusion the Perspective of a Special Didactics, Italian Journal of Health Education, Sports and Inclusive Didactics, Educating to the body for health and proper develoment, Edizioni Universitarie Romane.

Dewey, J. (2010). Arte come esperienza. Palermo: Aesthetica.

Edelman, M. G. (1992). Bright Air, Brilliant Fire: On the Matter of the Mind. New York: Basic Books.

Frabboni, F. (2004). II laboratorio. Roma-Bari: Laterza.

Friedrich, G., \& Preiss, G. (2003). Insegnare con la testa. Mente \& Cervello, (3).

Galbusera, L., Fuchs, T. (2013). Comprensione incarnata: Alla riscoperta del corpo dalle scienze cognitive alla psicoterapia, in rivista Mind Italia V 1-6.

Gamelli, I. (2011). Pedagogia del corpo. Milano: Raffaello Cortina Editore.

Gardner, H. (1975). The Shattered Mind, Random House Inc.

Gardner, H. (1999). Sapere per comprendere-Discipline di studio e disciplina della mente, Feltrinelli, Milano.

Goleman, D. (1995). Emotional Intelligence: Why It Can Matter More Than IQ. New York: Le Boulch, J. (1991). Verso una scienza del movimento umano. Introduzione alla psicocinetica. Roma: Armando Editore. 
Le Doux, J. (1996). The Emotional Brain. New York: Simon \& Schuster, Touchstone.

Maturana, H., Varela, F. J., (1980). Autopoiesis and Cognition: the Realization of the Living. Boston: D. Reidel ; trad. It., Autopoiesi e cognizione. La realizzazione del vivente. Venezia: Marsilio. https://doi.org/10.1007/978-94-009-8947-4

Mortari, L. (2003). Apprendere dall'esperienza: il pensare riflessivo nella formazione. Roma, Carocci.

Peluso Cassese, F. (2018). Motor Activity, Corporeity, Education, Inclusion the Perspective of a Special Didactics, Italian Journal of Health Education, Sports and Inclusive Didactics, Educating to the body for health and proper develoment, Edizioni Universitarie Romane.

Pouw T. J. L., van Gog T. (2014) An Embedded and Embodied Cognition Review of Instructional Manipulatives, Educational Psycology Review, V. 26, 1 pp 51/72.

Salovey, P. \& Mayer. J.D. (1990). Emotional intelligence. Imagination, Cognition and Personality, 9, 185211. https://doi.org/10.2190/DUGG-P24E-52WK-6CDG

Sibilio, M. (2005) Lo Sport Come Percorso Educativo: Attività Sportive E Forme Intellettive, Alfredo Guida Editore, Napoli.

Tafuri, D., Rosa, R., Di Palma, D., \& Ascione, A. (2019). An innovative Educational-Sport strategy to aim to inclusion: Biodanza SRT. Journal of Human Sport and Exercise, 14(1proc), S1-S10. https://doi.org/10.14198//hse.2019.14.Proc1.01

Thompson, E. (2007) Mind in life: Biology, phenomenology, and the sciences of mind, Cambridge. MA: Harvard University Press.

Toro Araneda, R. (2007) Biodanza: musica, movimento, comunicazione espressiva per lo sviluppo armonico della personalità, Edizioni Red, Como.

Toro Araneda, R. (2012). Teoria della Biodanza, raccolta dei testi a cura della A.L.A.B. (Associazione Latino-Americana di Biodanza), CIMEB testi, Volume I, Edizioni Nuova Prhomos, Perugia.

\section{(9) $(\mathbb{0} \Theta \Theta$}

This work is licensed under a Attribution-NonCommercial-NoDerivatives 4.0 International (CC BY-NC-ND 4.0). 